\section{Toxicity and disruption of quorum sensing in Aliivibrio fisheri by environmental chemicals: Impacts of selected contaminants and microplastics}

\author{
François Gagné \\ Aquatic Contaminants Research \\ Division, Environment and Climate \\ Change Canada, Montreal, Quebec, \\ Canada
}

\section{Abstract \\ The purpose of this study was to exam-} ine the effects of dissolved and particulate compounds on quorum sensing in the marine luminescent bacterium Aliivibrio fisheri. Bacteria were exposed to increasing concentrations of $\mathrm{CuSO}_{4}\left(\mathrm{Cu}^{2+}\right)$, gadolinium chloride $\left(\mathrm{Gd}^{3+}\right), 20$-nm silver nanoparticles (nanoAg) and 1-3 $\mu \mathrm{m}$ microplastic polyethylene beads for $250 \mathrm{~min}$. During this period, luminescence measurements were taken at 5-min intervals. Toxicity was first examined by measuring luminescence output at 5-min and 30-min incubation time. Based on the effective concentration that decreases luminescence by 20\% (EC20), the compounds were toxic at the following concentrations in decreasing toxicity: $\mathrm{Cu}^{2+}$ $(3.2 \mathrm{mg} / \mathrm{L})<\operatorname{nanoAg}(3.4 \mathrm{mg} / \mathrm{L}$, reported $)<$ $\mathrm{Gd}^{3+}(34 \mathrm{mg} / \mathrm{L})<$ microplastics $(2.6 \mathrm{~g} / \mathrm{L})$. The data revealed that luminescence changed non-linearly over time. In control bacteria, luminescence changed at eight specific major frequencies between 0.04 and 0.27 cycle/min after Fourier transformation of time-dependent luminescence data. The addition of dissolved $\mathrm{Cu}^{2+}$ and $\mathrm{Gd}^{3+}$ eliminated the amplitude changes at these frequencies in a concentration-dependent manner, indicating loss of quorum sensing between bacteria at concentrations below EC20. In the presence of nanoAg and microplastic beads, the decreases in amplitudes were modest but compressed the luminescence profiles, with shorter frequencies appearing at concentrations well below EC20. Thus, loss of communication between bacteria occurs at non-toxic concentrations. In addition, with exposure to a mixture of the above compounds at concentrations that do not produce effects for $\mathrm{Gd}^{3+}$, nanoAg and microplastics, $\mathrm{Cu}^{2+}$ toxicity was significantly enhanced, suggesting synergy. This study revealed for the first time that small microplastic particles and nanoparticles can disrupt quorum sensing in marine bacteria.

\section{Introduction}

To study toxic compounds in the aquatic environment, sensitive bioassays were developed for various organisms in the food chain, ranging from unicellular bacteria, yeasts and algae to multicellular organisms such as nematodes/annelids, mollusks, microcrustaceans and fish. ${ }^{1}$ The main advantage of these bioassay systems is that toxicity is measured in the environmental sample without prior knowledge of the compounds present in the testing media. However, in order to be used for routine screening, these assays should have the following features: low cost, quick and reproducible response to contaminants, high sample throughput, and modest laboratory equipment and space requirements. Bioassays, combined with biochemical markers, could also be used to unravel the mechanisms of the toxic effects. ${ }^{2}$ Luminescent bacteria were soon recognized as simple and quick bioassay system to examine the toxicity of various substances and complex mixtures; this was later commercially produced as the Microtox ${ }^{\mathrm{TM}}$ test for Aliivibrio fisheri. ${ }^{3}$

The bacterium Aliivibrio fisheri emits blue-green light during normal metabolism, which can be used as an indicator of viability, and this property was used as a toxic endpoint. The luminescence process is catalyzed by the luciferin-luciferase system. ${ }^{4}$ The reaction requires a flavin mononucleotide (FMNH2), a long chain aliphatic aldehyde and $\mathrm{O}_{2}$ to produce light: $\mathrm{FMNH}_{2}+$ $\mathrm{RCHO}+\mathrm{O}_{2}$ à $\mathrm{FMN}+\mathrm{RCOOH}+\mathrm{H}_{2} \mathrm{O}+\mathrm{h}$ 0. ${ }^{5}$ This reaction is catalyzed by bacterial luciferase and is synthesized by a process called quorum sensing, in which bacteria sense each other and adjust their respective metabolic activity accordingly. ${ }^{6}$ The enzyme synthesis occurs when cells exceed a threshold density. The substrates $\mathrm{FMNH}_{2}$ and $\mathrm{RCHO}$ are also produced by the bacteria, and $\mathrm{O}_{2}$ is obtained from the immediate environment. Recently, an oscillation in luminescence from stirred bacterial suspension was reported. ${ }^{7}$ Luminescence and ambient $\mathrm{O}_{2}$ concentration were found to be related: onset of luminescence is associated with decreased $\mathrm{O}_{2}$ content in the medium, and luminescence decreases as the $\mathrm{O}_{2}$ concentration drops and increases again as $\mathrm{O}_{2}$ re-enters the environment (e.g., as a result of stirring). Quorum sensing is also achieved through the production of small highly diffusible autoinducers (AIs) in the extracellular environment. Indeed, the luminescence of Aliivibrio fisheri, a luminescent bacterium that colonizes squids' light-emitting organ, is regulated by $\mathrm{O}_{2}$ availability and two known AIs: 3-oxohexanoyl 1-
Correspondence: François Gagné, Aquatic Contaminants Research Division, Environment and Climate Change Canada, 105 McGill, Montreal, Quebec, Canada, H2Y 2E7.

E-mail: francois.gagne@canada.ca

Key words: Aliivibrio fisheri, toxicity, quorum sensing, non-linear responses, silver nanoparticles, microplastics.

Acknowledgments: this work was funded by the Chemical Management Plan of Environment and Climate Change Canada. Kate Forster provided assistance with editing.

Received for publication: 26 September 2017 Revision received: 12 October 2017.

Accepted for publication: 3 November 2017.

This work is licensed under a Creative Commons Attribution NonCommercial 4.0 License (CC BY-NC 4.0).

(C) Copyright F. Gagné et al., 2017

Licensee PAGEPress, Italy

Journal of Xenobiotics 2017; 7:7101

doi:10.4081/xeno.2017.7101

homoserine lactone and octanoyl 1homoserine lactone. ${ }^{8,9}$ The luminescence signal peak is non-linear and is composed of at least two major peaks with a period of 150-225-min depending on the incubation conditions (Figure 1A).

Currently, the effects of environmental contaminants on quorum sensing in marine bacteria are not well understood. For example, the influence of metal ions such as copper $\left(\mathrm{Cu}^{2+}\right)$ and gadolinium $\left(\mathrm{Gd}^{3+}\right)$, which are common urban and industrial contaminants, on bacterial communication during adaptation to changes in dissolved $\mathrm{O}_{2}$ levels needs to be better understood. Moreover, the presence of emerging contaminants such as silver nanoparticles (nanoAg) $)^{10}$ and microplastics ${ }^{11}$ in marine ecosystems warrants investigation of their potential impact on quorum sensing in marine bacteria. The release of nanoparticles and micro/nanoplastic compounds has recently attracted much attention, as the marine environment is the final reservoir for these complex colloids and polymers. Micro(nano)plastics represent a considerable danger to the ecosystem because they are inadvertently ingested by various organisms during feeding and respiration. Moreover, microplastics and nanoparticles have the capacity to adsorb contaminants at orders of magnitudes higher than the surface water concentration and could thus act as vectors for contaminants. ${ }^{11-13}$

The purpose of this study was to exam- 
ine the effects of $\mathrm{Cu}^{2+}, \mathrm{Gd}^{3+}$, nanoAg and microplastic polyethylene beads on Aliivibrio fisheri toxicity and quorum sensing. Moreover, $\mathrm{Cu}^{2+}$ toxicity was examined in the presence of non-toxic concentrations of $\mathrm{Gd}^{3+}$, nanoAg and microplastic bead mixtures. Bacteria concentration was first optimized to initiate non-linear wave-like changes in luminescence and compared when the above substances were added in the incubation medium. An attempt was made to identify the mode of action of dissolved elements $\left(\mathrm{Cu}^{2+}\right.$ and $\left.\mathrm{Gd}^{3+}\right)$ and particles (nanoAg and microplastics) by analyzing quorum sensing changes in luminescence.
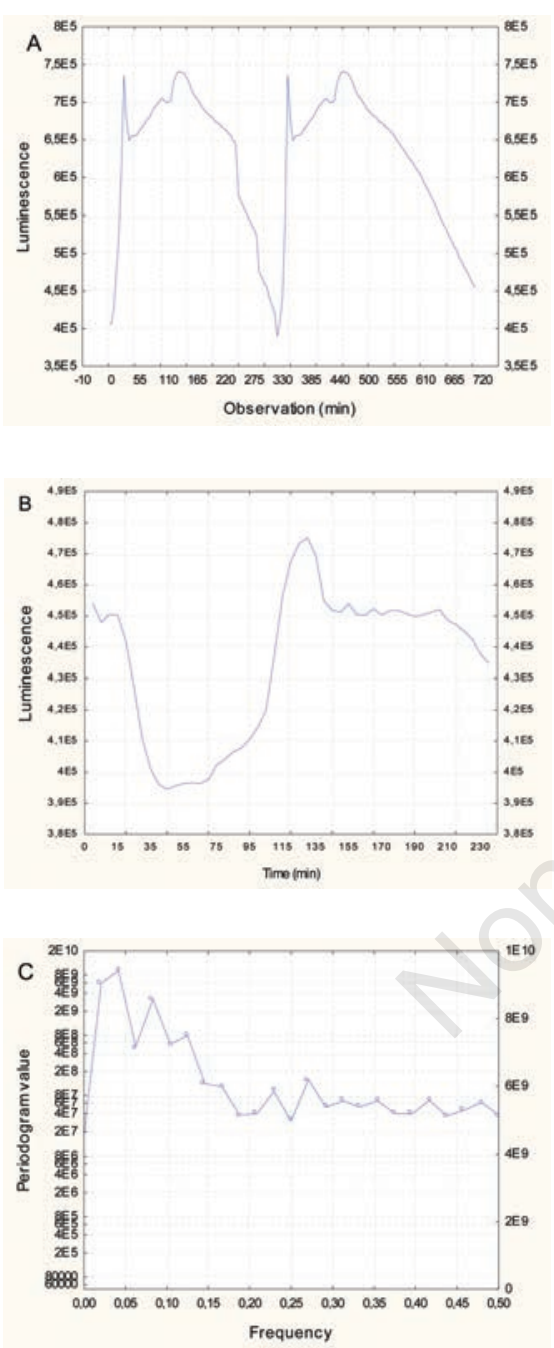

Figure 1. Change in luminescence in Allovibrio fisheri. Bacteria were re-suspended at 20 million cells $/ \mathrm{mL}$ in $2 \% \mathrm{NaCl}$ and luminescence was recorded at 5-min intervals for $3 \mathrm{~h}$ at $20^{\circ} \mathrm{C}$ under constant agitation. Luminescence oscillatory changes at 20 million cells $/ \mathrm{mL}$ (A), luminescence for the first 50 observations (250 min) and frequency domain analysis (C) are shown.

\section{Materials and Methods}

\section{Chemicals}

Copper sulfate $\left(\mathrm{CuSO}_{4}\right)$ and gadolinium chloride $(\mathrm{GdCl} 3)$ were purchased from Sigma Chemical Company (Ontario, Canada). Citrate-coated silver nanoparticles (1 $\mathrm{mg} / \mathrm{mL}$ stock solution, $20 \mathrm{~nm}$ mean diameter) were purchased from nanoComposix (Cederlane, Burlington, Canada). Microplastic beads (clear white polyethylene, 1-4 $\mu \mathrm{m}$ diameter) were purchased from Cospheric (California, USA). They were resuspended at $20 \mathrm{mg} / \mathrm{mL}$ in $2 \%$ $\mathrm{NaCl}$ and formed a homogenous suspension at this size range. Larger-size particles did not disperse in saline water and readily partitioned at the top of the solution.

Allivibrio fischeri bacteria were provided by the Microtox reagent (Microtox ${ }^{\circledR}$ Acute Reagent, Hoskin Scientific Ltd, Quebec City, Canada). The lyophilized bacteria were rehydrated in reconstitution media to obtain 100 million bacteria $/ \mathrm{mL}$ and kept on ice. The bacteria reagent suspension was then diluted at 20 million cells $/ \mathrm{mL}$ with $2 \% \mathrm{NaCl}$ in white microplates for luminescence measurements. It requires a critical amount of bacteria in a given volume to permit bacteria communication i.e., it requires an optimal concentration of cells for the bacteria to sense one other. The cells were exposed to $\mathrm{CuSO}_{4}(75,150$ and $300 \mu \mathrm{M}), \mathrm{GdCl}_{3}(30$, 60 and $120 \mu \mathrm{M})$, citrate-coated silver nanoparticles at $20 \mathrm{~nm}$ diameter $(125,250$ and $500 \mu \mathrm{g} / \mathrm{L}$ ) and microplastic polyethylene beads at $1-3 \mu \mathrm{m}$ diameter $(1,2$ and 4 $\mathrm{mg} / \mathrm{mL}$ ) in white 96 -well microplates. Bacteria were also exposed to the mixture of the above compounds at the lowest concentration: $75 \mu \mathrm{M}$ for $\mathrm{CuSO}_{4}, 30 \mu \mathrm{M}$ for $\mathrm{GdCl}_{3}, 125 \mathrm{ng} / \mathrm{L}$ for nanoAg and $1 \mathrm{mg} / \mathrm{mL}$ for polyethylene. Luminescence was measured with a microplate reader at 5-min intervals under constant agitation for $250 \mathrm{~min}$ (Synergy 4, Bioscan, microplate multireader, USA). In parallel, toxicity evaluation was also performed by measuring total luminescence after 5-min (acute) and 30min (subacute) exposure times.

\section{Data analysis}

The exposure experiments were repeated $\mathrm{N}=3$ times and mean luminescence values were reported at 5-min intervals for 250 min. The concentration that lowers bacterial luminescence by $20 \%$ (EC20) was calculated based on linear regression analysis. The data were also analyzed using Fourier transformation to determine the amplitude changes (periodogram) and frequency profiles (spectral analysis). Fourier analysis transforms any functions $f(x, t)$ into functions in the frequency domain $\mathrm{g}(\mathrm{k})$. More precisely, $\mathrm{g}(\mathrm{k})=\mathrm{a} 0+\Sigma[\mathrm{Ak} * \cos (2 \pi(\mathrm{kn} / \mathrm{N})$ $+\mathrm{Bk} * \sin (2 \pi(\mathrm{kn} / \mathrm{N})]$, where $n=1$ to $N$ observations (time in the present case). The variable $n$ represents the individual observations of the series expressed in time ( $\min )$, and $k$ is the frequency. The constants $A k$ and $B k$ are used to calculate the periodogram $(\mathrm{Pg})$ value, which is related to the amplitude variance of the sine and cosine

Table 1. Toxicity values of the selected contaminants.

\begin{tabular}{|c|c|c|c|c|}
\hline \multirow[t]{2}{*}{ Compounds } & \multicolumn{2}{|c|}{ Luminescence } & \multicolumn{2}{|c|}{ Estimated EC20 } \\
\hline & $5 \mathrm{~min}$ & $30 \mathrm{~min}$ & $5 \mathrm{~min}$ & $30 \mathrm{~min}$ \\
\hline Control $(2 \% \mathrm{NaCl})$ & 735437 & 649264 & --- & ---- \\
\hline $\begin{array}{c}\mathrm{Cu}(\mu \mathrm{M}) \\
75 \\
150 \\
300 \\
\end{array}$ & $\begin{array}{l}615774 \\
266366 \\
204577\end{array}$ & $\begin{array}{l}179205 \\
1033 \\
1675\end{array}$ & $\begin{array}{c}72 \mu \mathrm{M} \\
(11 \mathrm{mg} / \mathrm{L})\end{array}$ & $\begin{array}{c}20 \mu \mathrm{M} \\
(3.2 \mathrm{mg} / \mathrm{L})\end{array}$ \\
\hline $\begin{array}{c}\mathrm{Gd}(\mu \mathrm{M}) \\
30 \\
60 \\
120\end{array}$ & $\begin{array}{l}744437 \\
760047 \\
613066\end{array}$ & $\begin{array}{l}641904 \\
657822 \\
539850\end{array}$ & $\begin{array}{c}130 \mu \mathrm{M} \\
(34 \mathrm{mg} / \mathrm{L})\end{array}$ & $\begin{array}{c}130 \mu \mathrm{M} \\
(34 \mathrm{mg} / \mathrm{L})\end{array}$ \\
\hline $\begin{array}{l}n A g(\mu g / L) \\
20 \\
100 \\
500 \\
\end{array}$ & $\begin{array}{l}730566 \\
724344 \\
729743 \\
\end{array}$ & $\begin{array}{l}649718 \\
638901 \\
628745 \\
\end{array}$ & $>500 \mu \mathrm{g} / \mathrm{L}$ & $>500 \mu \mathrm{g} / \mathrm{L}$ \\
\hline $\begin{array}{l}\text { Polyethylene beads, } 1-3 \mu \mathrm{m}(\mathrm{mg} / \mathrm{mL}) \\
\quad 1 \\
2 \\
4\end{array}$ & $\begin{array}{l}722899 \\
675867 \\
565419\end{array}$ & $\begin{array}{l}622842 \\
562522 \\
405439\end{array}$ & $3.6 \mathrm{mg} / \mathrm{mL}$ & $2.6 \mathrm{mg} / \mathrm{mL}$ \\
\hline Mixture (lowest concentration of each) & 139644 & Nd & $\mathrm{Nd}$ & \\
\hline
\end{tabular}

$\mathrm{Nd}$, not determined. 
functions at each frequency $k: \operatorname{Pg}=\left(\mathrm{A}_{\mathrm{k}}{ }^{2}+\right.$ $\left.\mathrm{B}_{\mathrm{k}}{ }^{2}\right) * \mathrm{~N} / 2$, where $N$ is the total number of observations. The $\mathrm{Pg}$ value is thus related to the variance of the function at a given frequency. The significance of each Pg value was tested and compared to random noise using the Kolmogorov-Smirnov test (exponential adjustment). Phase shift analysis was also performed to determine changes in phases of the luminescence signal. All statistical tests were performed using the Statistica software package (France).

\section{Results}

The toxicity of the $\mathrm{Cu}^{2+}, \mathrm{Gd}^{3+}$, nanAg and polyethylene beads was examined at a concentration of 20 million cells $/ \mathrm{mL}$, which is higher than the concentration in the standard testing procedure (1 million bacteria/mL) ${ }^{14}$ (Environment Canada, 1992). Measurements were performed at $5 \mathrm{~min}$ and $30 \mathrm{~min}$ for the toxicity assessments. The decrease in luminescence is the measured endpoint for toxicity assessment. For $\mathrm{Cu}^{2+}$, a dramatic decrease in lumines- cence was observed: approximately 390fold at the highest concentration used. An estimated EC20 of $72 \mu \mathrm{M}$ and $20 \mu \mathrm{M}$ was observed after 5-min and 30-min exposure times respectively. For $\mathrm{Gd}^{3+}$, there was a moderate decrease: 1.2-fold at the highest tested concentration. An estimated EC20 of $130 \mu \mathrm{M} \mathrm{Gd}^{3+}$ was observed at 5-min and 30-min exposure times. For nanoAg, a low decrease in luminescence was observed, reaching only 1.3 -fold at the highest concentration tested, but EC20 was at concentrations higher than $500 \mu \mathrm{g} / \mathrm{L}$. For polyethylene microplastic beads, a 1.6-fold decrease was observed at the highest concentration. The estimated EC20 was 3.6 $\mathrm{mg} / \mathrm{mL}$ and $2.6 \mathrm{mg} / \mathrm{mL}$ for 5-min and 30 min exposure times respectively. As for the mixture, as explained in the Materials and Methods section, it decreased luminescence by 740 -fold compared to the control, which represented 200 times the decrease produced by $\mathrm{Cu}^{2+}$ alone at $75 \mu \mathrm{M}$. This indicates an important synergy between $\mathrm{Cu}^{2+}$ and $\mathrm{Gd}^{3+} /$ nanoAg/microplastics, given that the latter did not produce any significant effects alone at the lowest concentration tested. When bacteria density reached 20 million cells $/ \mathrm{mL}$ in $2 \% \mathrm{NaCl}$, luminescence changed non-linearly in time following a characteristic cyclic-like pattern (Figure 1B). The peak in luminescence lasted 120 to $150 \mathrm{~min}$. This process is associated with quorum sensing by bacteria populations, which is a function of oxygen availability and AI effects between bacteria for luminescence reaction. Fourier transformation of the data revealed that this signal could be broken down into major frequencies (Figure 1C). Indeed, we observed that the following eight frequencies were dominant: 0.020 , $0.042,0.0625,0.083,0.104,0.125,0.22$ and 0.27 . The most important frequencies were in the range of 0.042 to 0.10 , which corresponds to periods of 50 to $120 \mathrm{~min}$.

In bacteria exposed to $\mathrm{Cu}^{2+}$, a strong decrease in luminescence was observed at the lowest concentration $(75 \mu \mathrm{M})$, followed by an even stronger decrease in luminescence at higher concentrations (Figure 2A). The frequency profiles revealed that $\mathrm{Cu}^{2+}$ eliminated the signals in the range of 0.06 to 0.27 at the lowest concentration, suggesting loss of quorum sensing in the bacterial pop-
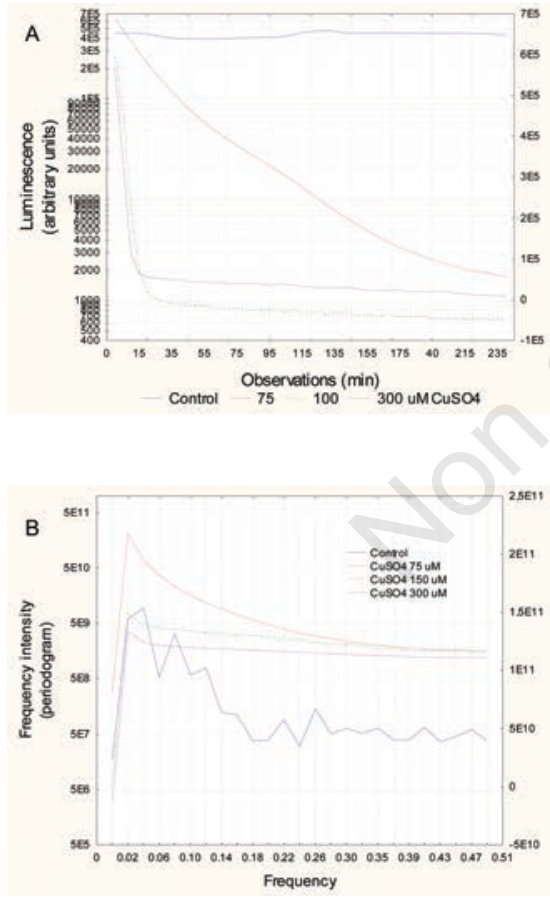

Figure 2. Change in luminescence in bacterial suspension exposed to CuSO4. Bacteria were re-suspended at 20 million cells $/ \mathrm{mL}$ in $2 \% \mathrm{NaCl}$ containing increasing concentrations of $\mathrm{CuSO}_{4}$. Luminescence was recorded at 5-min intervals for $3 \mathrm{~h}$ at $20^{\circ} \mathrm{C}$ under constant agitation. Recorded luminescence at each time (A) and frequency analysis by Fourier transformation (B) are shown.
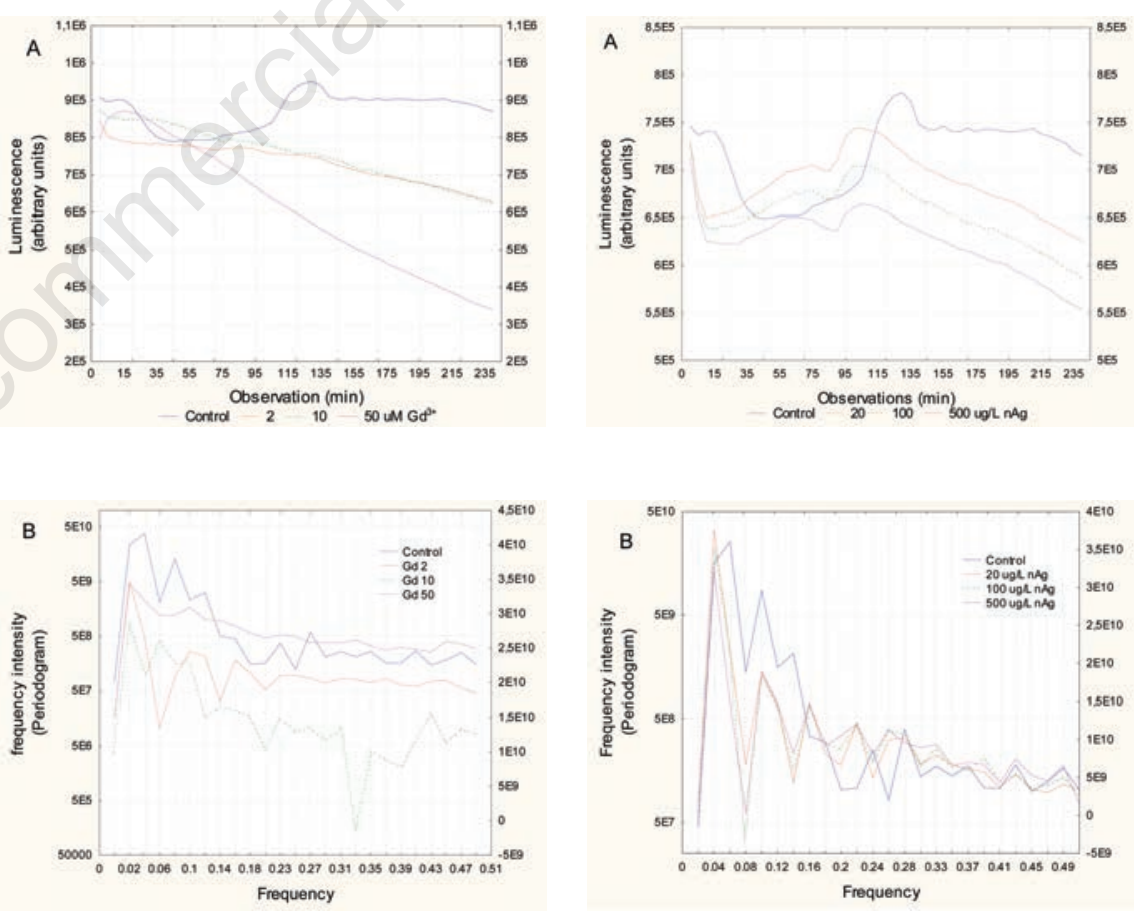

Figure 3. Changes in luminescence over time in bacteria exposed to Gd. Bacteria were re-suspended at 20 million cells $/ \mathrm{mL}$ in $2 \% \mathrm{NaCl}$ containing increasing concentrations of $\mathrm{GdCl} 3$. Luminescence was recorded at 5 -min intervals for $3 \mathrm{~h}$ at $20^{\circ} \mathrm{C}$ under constant agitation. Recorded luminescence at each time (A) and frequency analysis by Fourier transformation (B) are shown.

[Journal of Xenobiotics 2017; 7:7101]

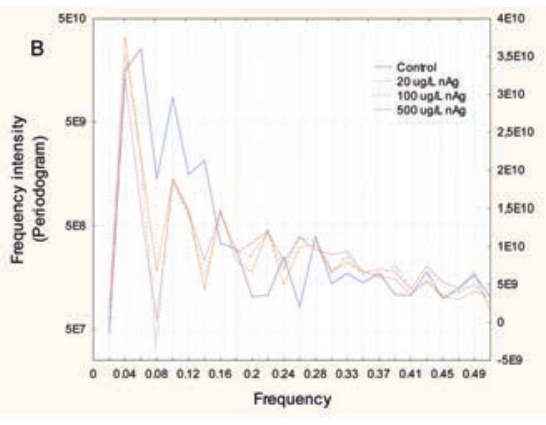

Figure 4. Change in luminescence over time in bacteria exposed to silver nanoparticles. Bacteria were re-suspended at 20 million cells $/ \mathrm{mL}$ in $2 \% \mathrm{NaCl}$ containing increasing concentrations of nanoAg. Luminescence was recorded at 5-min intervals for $3 \mathrm{~h}$ at $20^{\circ} \mathrm{C}$ under constant agitation. Recorded luminescence at each time (A) and frequency analysis by Fourier transformation (B) are shown. 
ulation. This occurs at the same range as the chronic (30-min) EC20. In bacteria exposed to $\mathrm{Gd}^{3+}$, a gradual decrease in luminescence was observed with the exposure concentration (Figure 3A). At the lowest exposure concentration, the curve still had a wavelike shape, but with very low amplitude changes (Figure 3B). Frequency analysis revealed a loss of signals at frequencies 0.06 to 0.1 , suggesting a decrease in communication between bacteria at concentrations $(30 \mu \mathrm{M})$ well below the reported EC20 $(130 \mu \mathrm{M})$ for $\mathrm{Gd}^{3+}$.

In bacteria exposed to nanoAg, the luminescence pattern did not change in appearance (Figure 4A). However, luminescence was lower than in the controls, and the pattern appeared out of phase compared to the controls. To show this, the $2^{\text {nd }}$ large peak at the $26^{\text {th }}$ observation $(130 \mathrm{~min})$ in controls was shifted to the $22^{\text {nd }}$ observation (110 $\mathrm{min}$ ) for all nano Ag concentrations. In addition, the peak height decreased in proportion to the nanoAg concentrations used. This was confirmed by phase shift analysis, which showed that the signals were shifted by a factor of 4 or 5 observations $(p=0.02)$. Frequency analysis revealed that the major signal intensities (periodogram) at frequencies 0.1 (period of $50 \mathrm{~min}), 0.08$ (62 $\mathrm{min})$ and 0.06 ( $83 \mathrm{~min}$ ) were lower than the controls and that the decreases were concentration-dependent (Figure 4B). This suggests that the presence of nano $\mathrm{Ag}$ in the incubation media disrupts bacterial communication, as shown by reduced luminescence and loss of signals at specific frequencies (0.06, 0.08 and 0.1$)$ at concentrations that do not produce toxic effects $(<\mathrm{EC} 20)$. In respect to microplastic polyethylene beads, the same pattern was observed with the nanoparticles (Figure 5A). There was a concentration-dependent loss of luminescence, especially at the $2^{\text {nd }}$ major peak $\left(26^{\text {th }}\right.$ observation). Bacteria exposed to microplastics also showed shifted spectra, but with a different behaviour. The major $2^{\text {nd }}$ peak $\left(26^{\text {th }}\right.$ observation or $130 \mathrm{~min}$ ) appeared to shift down to the $23^{\text {nd }}$ observation $(115 \mathrm{~min})$ at the lowest concentration of microplastics but shifted to the $35^{\text {th }}$ observation (175 min) at higher concentrations. These changes occurred at concentrations in the range of EC20. Frequency analysis revealed some changes in the frequency profiles (Figure $5 \mathrm{~B})$. A loss of signal at frequencies 0.06 , 0.08 and 0.1 was also found in bacteria exposed to microplastic beads. The control bacteria also exhibited characteristic minor peaks at higher frequencies 0.22 (115-min period) and 0.26 (95-min period) which was also systematically lost by all the compounds tested at the lower concentration respectively. We also examined the influ- ence of the mixture composed of each substance at the lowest concentrations on bacterial luminescence (results not shown). The mixture decreased luminescence and eliminated the frequency profiles, with only one signal at 0.02 -frequency. The intensity value of the signal was 22 times lower than for the control bacteria. To show the effects of the tested substances $\left(\mathrm{Cu}^{2+}, \mathrm{Gd}^{3+}\right.$, nanoAg, microplastic beads and mixture) on the luminescence profiles, a hierarchical tree analysis was performed on the first eight frequencies of the tested substances (Figure 6). The index of similarity between each substance (x axis) was expressed as 1$r$, where $r$ is the correlation coefficient of the first eight frequencies. The analysis revealed that the frequency profile (first eight frequencies) of the control had low similarity to bacteria exposed to all substances $(\mathrm{r}=0.575)$. The $\mathrm{Cu}^{2+}$ responses were very closely related to the mixture responses $(\mathrm{r}=0.99)$, which suggests that $\mathrm{Cu}^{2+}$ dominated the effects in the mixture (consistent with the fact that they were present at the lowest concentration for each, where $\mathrm{Cu}^{2+}$ only decreased luminescence on its own). $\mathrm{Gd}^{3+}$ responses were related to $\mathrm{Cu}^{2+}$, nanoAg and microplastics $(\mathrm{r}=0.825)$. The microplastics and nanoAg were highly correlated with each other $(\mathrm{r}=0.985)$, which suggests similar (colloidal-like) interactions.

\section{Discussion}

The reported toxicity of $\mathrm{Cu}^{2+}$ for the Microtox test is in the same range as in the present study with an EC50 of 1-2 mg/L. ${ }^{15}$ These values are close to the EC20 value of $3.2 \mathrm{mg} / \mathrm{L}$ obtained here, given that high bacteria concentration ( 20 million cells $/ \mathrm{mL}$ compared to 1 million cells $/ \mathrm{mL}$ ) was used. It is noteworthy that copper toxicity was enhanced 5 times when combined with the other compounds (which were not toxic on their own), suggesting synergy. Indeed, $\mathrm{Cu}^{2+}$ was the main driver of toxicity in the mixture, since the other compounds $\left(\mathrm{Gd}^{3+}\right.$, nanoAg and microplastic beads) did not produce toxicity at the concentrations used. Moreover, the lowest concentration of $\mathrm{Cu}^{2+}$, which was below EC20, completely eliminated luminescence signals over time, suggesting that $\mathrm{Cu}^{2+}$ disrupts quorum sensing in bacterial populations at sub-toxic concentrations. Loss of quorum sensing could be deleterious for the population since they would contribute to consume oxygen from its environment and contribute to decreased oxygen availability. Data on the aquatic toxicity of $\mathrm{Gd}^{+3}$ are scarce in the literature. A 7day exposure to lanthanum in Microcystis
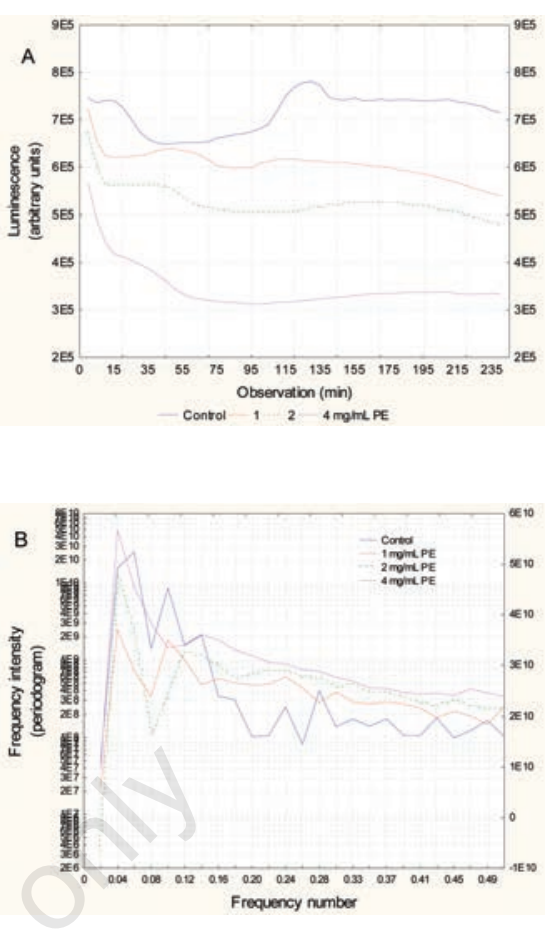

Figure 5. Luminescence change over time in bacteria exposed to microplastic beads (1-3 um). Bacteria were re-suspended at 20 million cells $/ \mathrm{mL}$ in $2 \% \mathrm{NaCl}$ containing increasing concentrations of polyethylene microplastic beads. Luminescence was recorded at 5-min intervals for $3 \mathrm{~h}$ at $20^{\circ} \mathrm{C}$ under constant agitation. Recorded luminescence at each time (A) and frequency analysis by Fourier transformation (B) are shown.

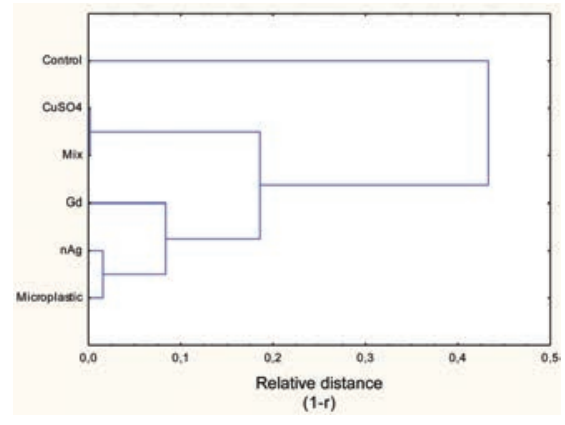

Figure 6. Hierarchical analyses of the first eight frequencies in luminescence changes. The periodogram value of the first eight frequencies was used to classify the quorum-sensing properties of the selected contaminants in bacterial suspension. Mixture was composed of the lowest concentration of $\mathrm{CuSO}_{4}(75 \mu \mathrm{M}), \mathrm{GdCl} 3(30 \mu \mathrm{M}), \mathbf{n A g}$ $(20 \mu \mathrm{g} / \mathrm{L})$ and microplastic beads (1 $\mathrm{mg} / \mathrm{mL})$. 
aeruginosa produced an NOEC value of $2.5 \mathrm{mg} / \mathrm{L}$ compared to the 30-min EC20 value of $34 \mathrm{mg} / \mathrm{L}$ for gadolinium. ${ }^{16} \mathrm{Gd}^{+3}$ decreased cell viability in primary cultures of rainbow trout hepatocytes at $250 \mathrm{mg} / \mathrm{L}$ in primary cultures of rainbow trout after 24 h. ${ }^{17}$ For nanoAg, the reported 30 -min toxicity with the standard Microtox test was 3.4 $\mathrm{mg} / \mathrm{L}$ for $20-\mathrm{nm}$ nanoparticles, ${ }^{18}$ which is well above the concentrations used in the present study. Nevertheless, changes in quorum sensing based on luminescence were observed at $20 \mu \mathrm{g} / \mathrm{L}$, which is about 170 times less than the EC50 value. Given the low Zeta potential for citrate-coated nanoAg, the nanoparticles are expected to be in aggregates as a result of charge neutralization due to the high salt $(\mathrm{NaCl})$ content of the incubation medium. ${ }^{19}$ The presence of conglomerates of nanoAg in the extracellular medium seems to dampen cell signaling by small diffusible small molecules (autoinducers). ${ }^{20}$ This raises the question of whether nanoAg could have somewhat of a binding effect on these AIs or act as a screen limiting diffusion between cells. It was found that individual cells vary in onset time of luminescence intensity, even in the presence of high concentrations of AIs. This indicates that luminescence phasing of cells leading to luminescence oscillations is a delicate mechanism and that the nature of the incubation medium and the presence of toxic compounds could readily influence bacteria communication. Microplastic polyethylene beads, which were in the same size range as bacteria (diameter of 1-3 $\mu \mathrm{m}$ ), likely remain in the intracellular media, leading to decreased luminescence and altering the signal over time. It is therefore possible, as with nanoAg aggregates that the presence of particles in the extracellular environment could act as a shield against signalling of $\mathrm{O}_{2}$ or AIs. Given that other contaminants could adhere to microplastics, ${ }^{11}$ this raises the possibility that microplastics could also bind signalling AI molecules involved in quorum sensing of bacterial populations. This is the first report of such an interaction between microplastics and bacterial luminescence. The observed changes in luminescence over time occurred at relatively large concentrations $(1 \mathrm{mg} / \mathrm{mL})$, which is unlikely in the water column but might occur in microenvironments such as tissues loaded with microplastics (e.g., gut or gills). ${ }^{21}$ Moreover, microplastics could degrade into nanoplastics (size range of 1 to $100 \mathrm{~nm}$ ), which could increase bioavailability and perhaps initiate toxicity at this scale through as yet unknown mechanisms or through vectorization or binding of essential biomolecules (AIs, hormones, cofac- tors, neurotransmitters, etc.). ${ }^{13}$ It was also observed that exposure to nanoparticles and microplastic beads compressed the luminescence profile somewhat and produced changes at lower frequencies. These changes in frequencies were also observed in NADH levels during glycolysis in Saccharomyces cerevisiae yeast cells exposed to various contaminants including $\mathrm{Gd}^{3+} .{ }^{22}$ Exposure of yeast cells for $3 \mathrm{~h}$ in nutrient-free media to $\mathrm{Cu}^{2+}, \mathrm{Gd}^{3+}$ and nanoAg led to the formation of higher frequencies in NADH levels with concentration-dependent amplitude changes. $\mathrm{Cu}^{2+}$ was the most toxic compound and produced changes at higher frequencies than the others, suggesting that toxicity manifests at different frequencies from the normal frequency spectrum.

\section{Conclusions}

In conclusion, the bacterial luminescence test commonly used in ecotoxicology to test for toxicity of liquid (and solid) samples could be adapted to determine the potential of compounds to disrupt quorum sensing by observing changes in luminescence at high bacteria density. At high density, a characteristic change in luminescence was observed: a periodic cycle of 150-200 min, with smaller changes at lower time scales. Fourier transformation revealed characteristic changes in luminescence at selected frequencies (eight major frequencies) between 0.04 and 0.27 cycles. The presence of ionic $\mathrm{Cu}$ and $\mathrm{Gd}$ clearly decreased luminescence output and eliminated these frequencies at concentrations that were usually lower than either the reported or measured acute toxicity values for Alivibrio fisheri. The presence of silver nanoparticles and microplastic beads led to a different change in luminescence profiles. The decrease in luminescence was smaller, but the luminescence profiles were somewhat compressed, with the appearance of shorter frequencies. Moreover, the observed changes in amplitudes and frequencies occurred at sub-toxic concentrations, suggesting that loss of quorum sensing occurs at low non-toxic concentrations. This study also revealed for the first time that microplastic beads could disrupt quorum sensing in bacterial populations.

\section{Highlights}

- Quorum sensing involves wave-like changes in luminescence in bacteria $A$. fisheri.

- The wave-like behavior in luminescence are changed by chemicals.
- Suspensions of silver nanoparticles and microplastics disrup chorum sensing in bacteria.

\section{References}

1. Blaise C, Gagné F, Bombardier M. Recent developments in microbiotesting and early millennium prospects. Water Air Soil Poll 2000;123:11.

2. Blaise C, Gagné F. Aquatic ecotoxicology: What has been accomplished and what lies ahead? An Eastern Canada historical perspective. J Xenobiotics 2013;3:e8.

3. Steinberg SM, Poziomek EJ, Engelmann W, Rogers K. A review of environmental applications of bioluminescence measurements. Chemosphere 1995;30:2155.

4. Raushel FM, Baldwin TO. Proposed mechanism for the bacterial bioluminescence reaction involving a dioxirane intermediate. Biochem Biophys Res Comm 1989;164:1137.

5. Balny C, Hastings JW. Fluorescence and bioluminescence of bacterial luciferase intermediates. Biochemistry 1975;14:4719.

6. Sasaki S. Oscillation in bacterial bioluminescence. In: D. Lapota, ed. Bioluminescence - Recent advances in oceanic measurements and laboratory applications. London: InTech; 2012. pp 167.

7. Sato Y, Sasaki S. Observation of Oscillation in Bacterial Luminescence. Analyt Sci 2008;24:423-5.

8. Eberhard A, Burlingame AL, Eberhard C, Kenyon GL, Nealson KH, Oppenheimer NJ. Structural identification of autoinducer of Photobacterium fischeri luciferase. Biochemistry 1981;28:2444-9.

9. Gilson L, Kuo A, Dunlap PV. AinS and a new family of autoinducer synthesis proteins. J Bacteriol 1995;177:6946.

10. Zuykov M, Pelletier E, Demers S. Colloidal complexed silver and silver nanoparticles in extrapallial fluid of Mytilus edulis. Mar Environ Res 2011;71:17.

11. Crawford C, Quinn B. Microplastic pollutants, $1^{\text {st }}$ ed. Amsterdam: Elsevier; 2016. pp 336.

12. Anderson JC, Park BJ, Palace VP. Microplastics in aquatic environments: Implications for Canadian ecosystems. Environ Poll 2016;18:269.

13. Gagné F, Gagnon C, Blaise C. Aquatic nanotoxicology: a review. Res Trends 2008;4:1-14.

14. Environment Canada. Biological test 
method. Toxicity test using luminescent bacteria SPE 1/RM/24. Montreal: Environment Canada; 1992.

15. Liu D, Dutka BJ. Toxicity screening procedures using bacterial systems. Boca Raton, FL: CRC Press; 1984.

16. Oosterhout F, Lürling M. The effect of phosphorus binding clay (Phoslocks) in mitigating cyanobacterial nuisance: a laboratory study on the effects on water quality variables and plankton. Hydrobiologia 2013;710:265.

17. Laville N, Ait-Aissa S, Gomez E, Casellas C, Porcher JM. Effects of human pharmaceuticals on cytotoxicity, EROD activity and ROS production in fish hepatocytes. Toxicology 2004; 196:41.

18. Jemec A, Kahru A, Potthoff A, Drobne D, Heinlaan M, Bohme S, et al. An interlaboratory comparison of nanosilver characterisation and hazard identification: Harmonising techniques for high quality data. Environ Intern 2016;87:20.

19. Gagné F, Auclair J, Fortier M, Bruneau A, Fournier M, Turcotte $\mathrm{P}$, et al. Bioavailability and immunotoxicity of silver nanoparticles to the freshwater mussel Elliptio complanata. J Toxicol Environ Health A 2014;76:767.

20. Delfino Perez P, Hagen SJ.
Heterogeneous response to a quorumsensing signal in the luminescence of individual Vibrio fischeri. PLoS One 2010;5:e15473.

21. Bouwmeester H, Hollman PCH, Peters RJB. Potential health impact of environmentally released micro- and nanoplastics in the human food production chain: experiences from nanotoxicology. Environ Sci Technol 2016;49:8932.

22. André C, Gagné F. Effect of the periodic properties of toxic stress on the oscillatory behaviour of glycolysis in yeast: evidence of a toxic effect frequency. Comp Biochem Physiol 2017;196:36. 